\title{
PERLINDUNGAN HUKUM TERHADAP KONSUMEN TERKAIT TIDAK ADANYA TANGGAL KADALUWARSA DIKEMASAN ROKOK*
}

Oleh:

\author{
I Gusti Ngurah Indra Semara Putra** \\ Dr. I Wayan Novy Purwanto, SH.,M.Kn*** \\ Bagian Hukum Perdata Fakultas Hukum Universitas Udayana
}

\begin{abstract}
Abstrak
Rokok salah satu barang yang paling digemari di kalangan masyarakat pada saat ini. Dilihat dari pengertiannya bahwa rokok itu gulungan tembakau kira-kira sebesar jari kelingking yang dikemas daun nipah, kertas yang nantinya akan menghasilkan asap setelah adanya pembakaran terhadap rokok tersebut. Banyaknya minat konsumen terhadap rokok menjadi peluang bagi pelaku usaha untuk berbuat curang atau tidak bertanggungjawab dengan tidak mencantumkan tanggal kadaluwarsa yang tidak sesuai dengan Undang-Undang Nomor 8 Tahun 1999 Tentang Perlindungan Konsumen. Hal ini banyak menimbulkan pertanyaan mengenai perlindungan hukum terhadap konsumen terkait penjualan rokok yang tidak mencantumkan tanggal kadaluwarsa dan untuk mengetahui sanksi terhadap pelaku usaha yang tidak mencantumkan tanggal kadaluwarsa di kemasan rokok. Penelitian ini diajukan untuk menganalisis dan mengetahui perlindungan hukum terhadap konsumen dan sanksi terhadap pelaku usaha yang tidak menerakan tanggal kadaluarsa.
\end{abstract}

Metode yang digunakan dalam penulisan ini adalah metode normatif dengan melihat adanya kekosongan norma pada ketentuan peraturan pada kemasan rokok terhadap UUPK yang mengharuskan produk yang dipasarkan memenuhi standar prosedur yang pada kali ini harus dicantumkannya tanggal kadaluarsa pada kemasan tersebut.

Hasil penelitian ini menunjukan bahwa konsumen berhak mendapat hak-haknya yang telah diatur dalam Undang-Undang Nomor 8 Tahun 1999 Tentang Perlindungan Konsumen apabila konsumen mengalami kerugian akibat kurang jelasnya informasi yang didapat maka konsumen berhak untuk meminta ganti kerugian dan pihak pelaku usaha wajib untuk bertanggung jawab.

\footnotetext{
* Karya Ilmiah ini merupakan karya ilmiah diluar ringkasan skripsi.

** I Gusti Ngurah Indra Semara Putra adalah mahasiswa Fakultas Hukum Universitas Udayana, Korespondensi: indrasemara21@gmail.com

*** Dr. I Wayan Novy Purwanto, S.H.,M.kn. adalah dosen Fakultas Hukum Universitas Udayana.
} 
Kata kunci: Rokok, Perlindungan Konsumen, informasi.

\begin{abstract}
Cigarettes are one of the most popular items in society today. Judging from the understanding that cigarettes are rolls of tobacco about the size of the little finger packed with nipah leaves, paper which will later produce smoke after the burning of the cigarette. The number of consumer interests towards cigarettes is an opportunity for businesses to cheat or not be responsible by not including expiration dates that are not in accordance with Law Number 8 of 1999 concerning Consumer Protection. This raises many questions about legal protection for consumers related to cigarette sales which do not include expiration dates and to find sanctions against business actors who do not include expiration dates on cigarette packages. This research was proposed to analyze and determine the legal protection of consumers and sanctions against business actors that do not impose an expiration date.

The method used in this paper is a normative method by looking at the absence of norms on the provisions of regulations on cigarette packaging to the UUPK which requires that the marketed product meet the standard procedures which at this time must be stated on the packaging expiration date.

The results of this study indicate that consumers have the right to get their rights as stipulated in Law Number 8 of 1999 concerning Consumer Protection if consumers suffer losses due to lack of clear information obtained, consumers have the right to request compensation and the business actor is obliged to be responsible.
\end{abstract}

\title{
Keywords: Cigarettes, Consumers Protection, information.
}

\section{Pendahuluan}

\subsection{Latar Belakang}

Rokok dapat memberikan permasalahan yang menyebabkan pengguna rokok dapat terkena penyakit kanker, penyakit paruparu, penyakit jantung, stroke, hipertensi bahkan juga diabetes sekali pun. Rokok disini merupakan zat adiktif, zat ini tergolong kedalam jenis obat dan makanan menurut Peraturan Kepala 
Badan Pengawas Obat dan Makanan RI Nomor 14 Tahun 2014 Tentang Organisasi dan Tata Kerja Unit Pelaksana Teknis Dilingkungan Badan Pengawas Obat dan Makanan. Munculnya bahaya dari merokok bukan lagi merupakan suatu jenis penyakit yang biasa melainkan sudah menjadi persoalan penyakit yang serius dan yang tidak jarang juga menyebabkan kematian. Berbagai terobosan yang mulai dibuat untuk mengenyampingkan efek samping dari rokok yang bisa membahayakan bagi kesehatan tubuh manusia.

Nikotin pada rokok yang secara berlebihan pun bisa akan mengakibatkan gangguan serius pada organ tubuh dikarenakan hal-hal yang kurang diperhatikan oleh pemakainya. UndangUndang Nomor 36 Tahun 2009 Tentang Kesehatan yang sebagaimana dimaksud dari Pasal 113 ayat (2). Yang termasuk kedalam zat adiktif yaitu produk yang mengandung tembakau, padat, cairan, dan gas yang bersifat adiktif dimana dapat menimbulkan kerugian bagi penggunanya dan atau masyarakat sekelilingnya. Hal yang mempunyai kesamaan tertuang kedalam Peraturan Pemerintah Nomor 109 Tahun 2012 Tentang Pengamanan Bahan Yang Mengandung Zat Adiktif Berupa Produk Tembakau Bagi Kesehatan. Dalam hal ini harus diperhatikan salah satunya di peraturan tersebut tidak adanya pembahasan yang mengkhusus mengenai pencantuman tanggal kadaluarsa pada kemasan rokok. Dilihat dari pengertian zat adiktif tersebut semakin harus berhati-hati dalam membeli dan menggunakannya. Dengan adanya pengertian tersebut bila diketemukannya rokok yang berada dikemasan tanpa tanggal kadaluarsa tersebut hal ini apakah kemasan rokok yang tanpa tanggal kadaluarsa bisa dipertanggung jawabkan. Disini faktor yang utama yang menjadi kelemahan pada konsumen adalah tingkat kesadaran akan 
haknya sangat rendah. ${ }^{1}$ Hingga detik ini pemerintah belum mengambil suatu keputusan yang tegas dalam hal peraturan mengenai rokok dikarenakan alasan devisa terbanyak datang dari pajak pembelian rokok. Kurang tegasnya pengawasan dari (BPOM) pengawasan dari Badan Pengawas Obat dan Makanan terbukti banyak adanya rokok yang dijual bebas tanpa tanggal kadaluarsa yang jelas. Hal tersebut tentu saja akan berdampak ke konsumen yang menggunakan rokok tersebut dalam jangka panjang.

Pencantuman tanggal kadaluarsa merupakan hal yang tidak boleh dilepaskan dalam pemasaran suatu produk. dikatakan kadaluarsa sendiri merupakan suatu kondisi dimana suatu produk dapat dikatakan melewati masa tempo waktu yang ditentukan. Ketidaklayakan kondisi tersebut sudah tentu tidak diperbolehkan untuk dijual, dalam hal ini konsumen, harus cerdas dan teliti dalam membeli suatu poduk. Perlindungan konsumen harus lebih serius lagi untuk di tingkatkan untuk melindungi hak-hak dari konsumen. Undang-undang Nomor 8 Tahun 1999 menjadikan regulasi yang terdepan yang memiliki ketentuan bahwa perlindungan konsumen merupakan kepentingan masyarakat wujud dari itu semua dilihat dari berbagai hubungan yang satu sama lainnya harus saling terkait, hubungan antara konsumen, pelaku usaha dan pemerintah. Jadi Undang-Undang Nomor 8 Tahun 1999 belum berjalan secara efektif dan belum tegasnya pemerintah dalam menegaskan peraturan tentang rokok terutama dalam pencantuman tanggal kadaluarsa pada kemasan rokok yang dipasarkan. Sehingga dapat dikatakan terjadinya kekosongan norma dalam pengaturan bahan

${ }^{1}$ Agung Brahmanta A.A Gde. Perlindungan Hukum Bagi Konsumen Dalam Perjanjian Baku Jual Beli Perumahan Dengan Pihak Pengembang di Bali. Jurnal Acta Comitas udayana Vol. 1, edisi oktober 2016. https://ojs.unud.ac.id/index.php/ActaComitas/article/view/24953. diakses tanggal 2 oktober 2016. https://doi.org/10.24843/AC.2016.v01.i02.p08 
yang mengandung zat adiktif yang tidak mengatur terkait tanggal kadaluarsa melainkan tanggal produksi saja sehingga tidak sesuai dengan UUPK, serta kurang diperhatikannya informasi yang jelas, jujur kepada masyarakat akan hal tersebut. Terlepas dari bagaimana pengaturan mengenai suatu perlindungan konsumen terhadap pencantuman tanggal kadaluarsa di kemasan rokok yang dipasarkan. Dalam penelitian ini akan dibahas juga mengenai sanksi apabila terdapat suatu penyebaran kemasan rokok yang tidak memiliki tanggal kadaluarsa. Dengan pengertian bahwa perlindungan hukum itu adalah perlindungan hukum yang di berikan oleh hukum terhadap hak dan kewajiban manusia. Sehingga perlindungan hukum itu ada dan diterapkan kepada pelanggarnya. $^{2}$

\subsection{Rumusan Masalah}

Berdasarkan latar belakang masalah yang telah dikemukakan diatas maka dibuatlah rumusan masalah yang akan nantinya dibahas pada bab pembahasan yaitu:

1. Bagaimana perlindungan hukumnya bagi konsumen terhadap kemasan rokok yang tidak mencantumkan tanggal kadaluarsa?

2. Bagaimana peran BPOM berkaitan dengan kemasan rokok yang tidak mencantumkan tanggal kadaluarsa?

\subsection{Tujuan Penelitian}

2 Januaryanti Pande Ni Putu, Perlindungan Konsumen Terhadap Produk Kosmetik Impor Yang Tidak Terdaftar di BPOM Denpasar, Jurnal Magister HukumUdayanaVol.6edisimei2017.https://ojs.unud.ac.id/index.php/jmhu/arti cle/view/22288/20922.diaksespadahttps://doi.org/10.24843/JMHU.2017.v06. 101.p02 
Untuk mengetahui sanksi yang akan diterapkan apabila terdapat suatu penyebaran kemasan rokok yang tidak mencantumkan tanggal kadaluarsa pada kemasan rokok. dan Untuk mengetahui pengaturan mengenai suatu perlindungan konsumen terhadap kemasan rokok yang tidak dicantumkannya tanggal kadaluarsanya.

\section{Isi Makalah}

\subsection{Metode Penelitian}

penelitian ini menggunakan jenis penelitian hukum normatif dikarenakan penelitian ini mengkaji dan meneliti suatu peraturanperaturan tertulis. Perlu adanya penelitian hukum normatif ini agar dapat memberikan suatu informasi jelas bagaimana perlindungan konsumen terhadap kemasan pada rokok yang tidak mencantumkan tanggal kadaluarsa.

\subsection{Hasil dan analis}

\subsubsection{Perlindungan hukumnya bagi konsumen terhadap} kemasan rokok yang tidak mencantumkan tanggal kadaluarsa

Perlunya perlindungan hukum terhadap konsumen hak konsumen atas barang dan/atau jasa yang nyaman, aman, dan pastinya baik bagi kesehatan tubuh dengan tidak membahayakan keselamatan jasmani ketika konsumen dalam hal ini mengonsumsi suatu barang yang dibelinya. Pencantuman tanggal kadaluarsa pada kemasan rokok merupakan hal yang harus dan wajib di lakukan oleh suatu pelaku usaha dilihat dari UUPK. Dengan tidak mencantumkan tanggal kadaluarsa tersebut maka masyarakat atau konsumen akan sulit mengetahui rokok dan membedakan mana rokok yang layak untuk di gunakan/ 
dikonsumsi dengan rokok yang tidak layak untuk di gunakan/dikonsumsi.

Adanya suatu peraturan dalam kaitannya dengan konsumen diatas telah lahirnya Undang-undang Nomor 8 Tahun 1999 tentang Perlindungan Konsumen yang dimana pada Pasal 1 angka satu menyatakan bahwa adanya suatu hal dalam mengenai perlindungan konsumen dalam hal ini setiap usaha harus memberikan suatu jaminan kepastian hukum guna memberikan suatu kesatuan perlindungan bagi para konsumen. ${ }^{3}$ Adanya perlindungan bagi para konsumen akan menjadikan sebuah pondasi untuk melindungi para konsumen agar tetap merasakan keamanan. Dalam hal ini juga perlindungan konsumen sangat diperioritaskan guna dalam kesejahteraan dan kemakmuran rakyatnya terutama dibidang perekonomian masyarakat pada era ini. Dengan adanya aturan yang di keluarkan ini hak yang dimiliki oleh konsumen sangat terjaga. Pencantuman tanggal kadaluarsa pada kemasan rokok yang dipasarkan bagi para pelaku usaha lainnya dalam hal ini pelaku usaha sepatutnya memberikan hak konsumen atas informasi yang benar, jelas dan jujur, dan akan mencapai sebuah kondisi rokok yang terjamin dalam pemakaiannya. Informasi yang jelas dalam hal pencantuman tanggal kadaluarsa pada kemasan rokok yang dipasarkan ini adalah sebuah hak yang dimiliki oleh konsumen, sehingga dalam membeli suatu benda/barang produk yang dipasarkan para konsumen tidak akan pernah cemas lagi untuk memilih benda/barang sebuah produk tersebut. ${ }^{4}$ Namun dengan hal adanya sebuah aturan ini dengan sangat jelas disebutkannya

3 Shidarta, 2000, Hukum Perlindungan Konsumen, Grasindo, Jakarta, h. 11

${ }^{4}$ Husni Syawali, dan Neni Sri Imaniyati, 2000, Hukum Perlindungan Konsumen, Mandar Maju, Bandung, h.18 
dalam suatu Undang-undang tentang perlindungan hukum bagi konsumen, membuat para pelaku usaha semakin mebandel, ada saja masih pelaku usaha yang melakukan hal yang dapat mengakibatkan merugikan dengan para konsumennya, sehingga perlunya peningkatan hukumnya terhdap perlindungan konsumen dalam membeli sebuah produk yang dipasarkan di masyarakat, dunia, dan khususnya di wilayah Indonesia.

Diperlukannya Undang-Undang Perlindungan Konsumen (UUPK), karena ada masyarakat yang tidak tau dengan produk yang di pasarkan oleh pelaku usaha seperti halnya, tingkat kelayakan sebuah produk yang dipasarkan tersebut. Dilihat dari sebuah tujuan hukum yang menghasilkan atau memastikan seseorang untuk mendapatkan suatu kepastian hukum dalam masyarakat sedangkan hukum dari perlindungan konsumen secara mendahulu/langsung mempunyai tujuan untuk meningkatkan martabat dan meningkatkan suatu kesadaran pada masyarakat konsumen. Ada pula tujuan yang secara tidak langsung yakni sebagai pendorong bagi suatu pelaku usaha untuk melakukan kegiatan usaha dengan penuh rasa tanggung jawabnya. 5 Tercapainya sebuah keseimbangan terhadap perlindungan konsumen, dapatnya dilakukan dengan cara menegakan suatu aturan dalam hal ini UUPK yang menjamin hakhak konsumen. ${ }^{6}$ Yang menjadi hak-hakn konsumen yang dituangkan di dalam Undang-undang Nomor 8 Tahun 1999 Tentang Perlindungan Konsumen dalam Pasal 4 huruf c, bahwasannya hak konsumen adalah:

${ }^{5}$ Adrian Sutedi, 2008, tanggung jawab produk dalam hal perlindungan konsumen, Ghalia Indonesia, Bogor, h.9

${ }^{6}$ Ahmadani Miru, 2013, prinsip-prinsip perlindungan hukum bagi konsumendi Indonesia, cet.2 Rajawali Pres, Jakarta, h.102 
"Hak atas informasi yang benar, jelas dan jujur mengenai suatu kondisi dan jaminan suatu barang dan/atau jasa".

pada Pasal 4 huruf c tersebut, bisa dikatakan pelaku usaha yang terbukti melakukan suatu perbuatan penjualan tanpa dicantumkannya tanggal kadaluarsa pada kemasan suatu produk dalam hal ini telah melanggar hak konsumen yang dituankan di dalam Pasal 4 huruf c, yakni setiap konsumen berhak atas informasi yang jelas, benar, jujur, mengenai kondisi dan jaminan suatu barang yang di produksi. Informasi disini sangatlah penting bagi para pelaku usaha dalam memproduksi produk, karena jika tidak adanya informasi yang jelas dan memadai kepada konsumen dapat dikatakan bahwasanya suatu produk tersebut bisa dikatakan sebagai suatu produk yang cacat produk. Disini informasi yang memadai dimiliki oleh konsumen dengan memberikan sebuah gambaran yang tepat mengenai suatu produk karena dengan adanya informasi ini konsumen dapat dengan selektif memilih produk yang diinginkan yang dapat menghindarkannya dari suatu kerugian akibat kesalahan dalam penggunaan suatu produk. ${ }^{7}$ Jika adanya suatu hak yang tidak didapatkan oleh konsumen, tentu disini pelaku usaha memiki kewajiban untuk memberikan ganti kerugian danatau konpensasi sesuai dengan ketentuan Pasal 7 UUPK, yang menyatakan kewajiban pelaku usaha dalam hal:

"memberikan informasi yang benar, jelas dan jujur mengenai kondisi dan jaminan barang dan atau jasa serta memberi penjelasan penggunaan, perbaikan, dan pemeliharaan".

Adanya ketentuan yang di muat dalam uraian diatas, bahwa pelaku usaha yang tidak mencantumkan tanggal kadaluarsa pada produk kemasan rokok jelas disini akan terjadi pertentangan

${ }^{7}$ Ibid, h.105 
antara kewajiban suatu pelaku usaha yang tertuang pada Pasal 7 huruf $b$ UUPK. bila terdapat konsumen yang merasa dirugikan/dibohongi maka hal tersebut menjadi kewajiban pelaku usaha untuk menggantikan ganti rugi dan/ atau kompensasi sesuai dengan Pasal ini yang dikatakannya bahwa suatu pelaku usaha harus memberikan suatu informasi yang jelas, benar, dan jujur mengenai kondisi dan jaminan barang dan/atau jasa serta dilengkapi dengan cara penggunaan, perbaikan, dan pemeliharaan.

Kerugian yang diganti oleh pelaku usaha yang dapat merugikan konsumen, dilakukan dengan upaya hukum dengan tujuan mencegah terjadinya suatu pelanggaran atas hak-hak yang dimiliki oleh konsumen agar mendapatkan suatu perlindungan hukum yang tegas dan jelas bagi pelaku usaha sehingga kelompok atau gerombolan orang mendapatkan jaminan perlidungan dalam hukum dan memberikan suatu kepastian hukum. Hal ini menunjukan bahwa tugas seorang produsen tidak berakhir dengan menempatkan suatu produk sirkulasi saja. Dengan adanya suatu aturan hukum yang diatur dalam UUPK ( undangundang perlindungan konsumen) diharapkan agar konsumen mendapatkan suatu perlindungan hukum yang jelas dan dapatnya konsumen melakukan tuntutan apabila nantinya ada suatu kerugian yang ditimbulkan, dirasakan akibat dari penjualan rokok yang tidak mencantumkan tanggal kadaluarsa pada kemasan rokok yang dipasarkan

\subsubsection{Peranan BPOM berkaitan dengan kemasan rokok yang tidak mencantumkan tanggal kadaluarsa?}

Berdasarkan pasal 2 Peraturan kepala BPOM Nomor 14, BPOM mempunyai tugas melaksanakan kebijkan dibidang pengawasan obat dan makanan, yang meliputi pengawasan atas 
Produk Terapetik, Narkotika, psikotropika, Zat Adiktif, Obat tradisional, kosmetik, produk komplemen serta pengawasan atas keamanan pangan dan bahan berbahaya. Dan BPOM memiliki fungsi yang sebagaimana dijelaskan bahwa Fungsi utama BPOM berdasarkan Pasal 68 Keputusan Presiden Nomor 103 Tahun 2001 salah satunya dalam pelaksanaan kebijakan tertentu dibidang pengawasan obat dan makanan. Peran BPOM salah satunya penetapan persyaratan penggunaan bahan tambahan (Zat Adiktif) tertentu untuk makanan dan penetapan pedoman peredaran obat dan makan. BPOM juga menentukan penggolongan rokok yang digolongkan sebagai salah satu Zat adiktif yang termasuk kedalam Badan Pengawas Obat dan Makanan(BPOM) yang tertuang pada peraturan kepala badan pengawas obat dan makanan RI Nomor 14 Tahun 2014 Tentang Organisasi dan Tata Kerja Unit Pelaksanaan Teknis Dilingkungan Badan Pengawas Obat dan Makanan, mengenai zat tersebut harus diawasi keberadaannya untuk mengantisipasi pemakaiannya agar tidak meluas dan tidak berlanjut pada generasi muda berikutnya. Agar nantinya mereka mengetahui seberapa bahayanya rokok tersebut bagi kesehatan dan menanggapi masalah yang terjadi ini, BPOM juga berperan untuk mengawasi jalannya pemasaran dalam suatu produk. Dikaitkan dengan Undang-Undang perlindungan konsumen dan Peraturan Pemerintah Nomor 109 Tahun 2012 mengenai Pengamanan Bahan Yang Mengandung Zat Adiktif Berupa Produk Tembakau Bagi Kesehatan. Pada ketentuan peraturan pemerintah tersebut tidak adanya peraturan mengenai pencantuman tanggal kadaluarsa pada rokok sedangkan di UUPK sendiri suatu pelaku usaha wajib mencantumkan tanggal kadaluarsa dalam suatu produk yang diproduksinya. Dalam hal ini BPOM mengatakan juga bahwa suatu produk yang masuk ke dalam negeri dalam 
lingkungan sehari-hari harus diawasi dan harus mencantumkan ketentuan informasi yang jelas, benar, dan jujur salah satunya dalam pencantuman tanggal kadaluarsa pada kemasan rokok tersebut. Dan BPOM mengatakan bahwa Pelaku usaha wajib memenuhi syarat-syarat yang tercantum dalam UUPK sehingga nantinya konsumen mendapat perlindungan hukum mengenai produk yang akan dibeli agar lebih mendapat kepastian yang jelas maupun informasi yang benar dan jujur dari pelaku usaha terhadap barang yang diproduksinya. Adanya tanggung jawab pelaku usaha yang tertuang pada Pasal 8 huruf g ayat 1 .

"Perbuatan suatu Pelaku usaha yang dilarang dengan tidak mencantumkannya tanggal kadaluarsa atau dengan kata lain jangka waktu penggunaan/pemanfaatan yang paling baik atas barang tertentu". Jadi setiap perbuatan melawan ataupun melanggar hukum harus menanggung sanksi sesuai dengan peraturan yang ada. Tanggung jawab pelaku usaha telah diatur dalam UUPK yang terdapat pada Pasal 19.

Apabila pelaku usaha yang telah terbukti merugikan para konsumen dan tidak mau bertanggung jawab akan hal perbuatannya tersebut maka para konsumen yang merasa di rugikan dapat menggugat pelaku usaha melalui badan peradilan ditempat kedudukan konsumen tersebut dengan menyesuaikan ketentuan yang ada pada Pasal 23 UUPK.

\section{PENUTUP}

\subsection{Kesimpulan}

Dengan hasil dari analisis yang ada pada karya ilmiah diatas mendapatkan kesimpulan Terkait dengan perlindungan hukum terdapat rokok yang tidak adanya tanggal kadaluarsa pada kemasan rokok yang dipasarkan, Yang pada kesempatan kali ini 
melihat dan meninjau dari pasal yang ada pada Undang-undang Perlindungan Konsumen atau yang disingkat dengan (UUPK) yaitu:

1). Perlindungan hukum terhadap konsumen terkaitnya dengan penjualan rokok yang tidak mencantumkan tanggal kadaluarsa pada kemasan rokok tercantum kedalam Pasal 4 huruf c, pemberian informasi yang jelas merupakan kewajiban dari pelaku usaha Pasal 7 huruf $b$, dan perlindungan terhadap konsumen yang telah dirugikan diatur didalam Pasal 8 huruf g mengenai hal yang dilarang dari suatu pelaku usaha.

2. Peran BPOM dalam mengawasi dan menentukan penggolongan rokok juga memberikan informasi bahwa suatu pelaku usaha wajib mencantumkan tanggal kadaluarsa pada barang dan atau/ jasa yang diproduksinya agar konsumen mendapatkan haknya dan pemerintah ikut dalam melakukan pembinaan untuk mengawasi terjadinya kecurangan Pelaku usaha jika ada suatu kecurangam maka pelaku usaha mempunyai tanggungjawab perbuatannya dengan memberikan ganti rugi baik berupa pengembalian sejumlah uang, atau penggantian sebuah barang dengan dasar Pasal 19 UUPK. Konsumen disini dapat melakukan penggugatan kepada pelaku usaha yang tidak mau bertanggung jawab atas perbuatannya dengan BPSK.

\subsection{Saran}

Berdasarkan dari kesimpulan mengenai tidak adanya pencantuman tanggal kadaluarsa pada kemasan rokok diatas didapatlah 2 saran yaitu:

1).Banyaknya peristiwa yang terjadi mengenai penjualan rokok yang tidak mencantumkan tanggal kadaluarsa pada kemasan 
rokok mengharuskan para konsumen melakukan ekstra teliti dalam memilah dan memilih untuk membeli suatu produk ataubarang yang di jual belikan di pasaran oleh pelaku usaha. Dengan memberikan informasi yang jelas, benar, dan jujur atas barang yang di pasarkan dan diedarkan di pasar harus lebih memperhatikan hak-hak konsumen merupakan keharusan dan kewajiban bagi pelaku usaha.

2). Adanya peran BPOM dalam hal melakukan pengawasan untuk menyeimbangkan suatu hak-hak konsumen dengan pelaku usaha diperlukan pemberian biaya tambahan sehingga pihak BPOM lebi semangat dalam melaksanakan tugas dalam mengawasi jalannya suatu produksi suatu barang atau jasa yang pada kali ini bahan obat dan makanan. Dan disini hendaknya konsumen harus jeli, memilih dan memilah suatu barang yang akan di beli agar tidak terjai suatu kecurangan terhadap pelaku usaha dan para konsumen tidak merasa dirugikan dengan tidak adanya tanggal kadaluarsa pada kemasan rokok yang ada di pasaran dan perlunya mengkaji kembali pengaturan aturan terkait rokok. Dengan memberikan suatu aturan yang mengkhusus, kekhwatiran yang ada pada masyarakat memiliki jawaban dan memiliki pelindung dari pada hukum untuk memberikan suatu kepastian hukum. 


\section{DAFTAR PUSTAKA}

\section{Buku}

Muthiah, Aulia, 2018, Hukum Perlindungan Konsumen, Pustaka Baru Press, Yogyakarta.

Miru Ahmadi, 2013, Prinsip-prinsip Perlindungan Hukum bagi Konsumen Di Indonesia, cet.2. Rajawali Pres, Jakarta.

Wulandari Rezky dan Tadjuddin Nurdiyana, 2018, Hukum Perlindungan Konsumen, Mitra Wacana Media, Jakarta.

Shidarta, 2000, Hukum Perlindungan Konsumen, Grasindo, Jakarta.

Tri Siwi Kristiyanti, Celina, 2014, Hukum Perlindungan

Konsumen, Sinar Grafika, Jakarta.

Sutedi, Adrian, 2008, Tanggung Jawab Produk Dalam Perlindungan Konsumen, Ghalia Indonesia, Bogor.

\section{Peraturan Perundang-undangan}

Undang-Undang Nomor 8 Tahun 1999 Tentang Perlindungan Konsumen (Lembaran Negara Republik Indonesia Tahun 1999 Nomor 42 Tambahan Lembaran Negara Republik Indonesia Nomor 3821).

\section{Jurnal}

A.A Gde Agung Brahmanta, Perlindungan Hukum Bagi Konsumen Dalam Perjanjian Baku Jual Beli Perumahan Dengan Pihak Pengembang di Bali, Jurnal Acta Comitas udayana Vol.1 edisioktober2016.https://ojs.unud.ac.id/index.php/ActaCo mitas/article/view/24953. diakses tanggal 2 oktober 2016. https://doi.org/10.24843/AC.2016.v01.i02.p08

Ni Putu Januaryanti Pande, Perlindungan Konsumen Terhadap Produk Kosmetik Impor Yang Tidak Terdaftar di BPOM Denpasar, Jurnal Magister Hukum Udayana Vol.6 edisi mei 2017.https://ojs.unud.ac.id/index.php/imhu/article/view/ 22288/20922.diaksespadahttps://doi.org/10.24843/JMHU. 2017.v06.i01.p02 